\title{
Rhabdomyolysis and Myocardial Damage Induced by Palytoxin, a Toxin of Blue Humphead Parrotfish
}

\author{
Hiroshi Okano, Hiroshi Masuoka, Shigeru Kamei, Tetsuya Seko, Sukenari Koyabu, \\ Katsunobu Tsuneoka, Takuya Tamai, Kunihiko Ueda, Shigeo Nakazawa, Masahiro Sugawa, \\ Hideo Suzuki*, Masatoshi Watanabe*, Ryuichi Yatani* and Takeshi NaKano**
}

\begin{abstract}
A 55-year-old man had rhabdomyolysis and myocardial damage induced by palytoxin. Weakness and myalgia of four extremities occurred five hours after eating a fish. Rhabdomyolysis developed and the serum creatine phosphokinase (CK) was elevated to 40,000 IU/l on the 3rd day. Gastric lavage with activated charcoal and forced mannitol-alkaline diuresis therapy were performed. The patient recovered with no complication such as renal failure. In this case, palytoxin was suggested to induce myocardial damage which was demonstrated by an elevation of the myosin light chain level and a change in electrocardiogram.
\end{abstract}

(Internal Medicine 37: 330-333, 1998)

Key words: myosin light chain, creatine phosphokinase, food poisoning

\section{Introduction}

Despite dramatic advances in food sanitation procedures during the 20th century, acute food-borne disease caused by infectious agents and chemical toxins remains an important problem. It is customary in Japan for people to eat raw fish. Poisoning caused by poisonous fish, such as a swellfish (tetrodotoxin) has been reported. We report a rare case of rhabdomyolysis after eating blue humphead parrotfish [Ypsiscarus ovifrons] (Fig. 1).

\section{Case Report}

A 55-year-old Japanese male was admitted to our hospital because of the weakness and myalgia of four extremities on March 26, 1996. Five hours before the admission, he and his friends ate an "aobudai" (Blue humphead parrotfish [Ypsiscarus ovifrons]) that they had caught in the cove of Owase. Only the patient ate the raw meat and liver from the fish. His friends ate cooked fish and developed no symptoms.

On admission, his body temperature was $35.3^{\circ} \mathrm{C}$, the pulse rate was 80 , and the respirations were 20 per minute. The blood pressure was $180 / 100 \mathrm{mmHg}$. He was moving all extremities with power rated at $4+/ 5$ proximally and distally. He could walk without assistance. The widebase or ataxia of gait were not observed. Deep tendon reflexes were 1+ in all the extremities.
Babinski signs were not observed. Muscle swelling and tenderness were not present, and the sensory examinations were normal.

The laboratory data on the admission revealed elevated white blood cells, creatine phosphokinase (CK), aspartate aminotransferase (AST), alanine aminotransferase (ALT), lactate dehydrogenase (LDH) and C-reactive protein (CRP), as shown in Table 1. The renal function and the arterial blood gas analysis were kept almost normal (Table 1). There were no abnormalities in the electrocardiogram, chest and abdominal X-ray on admission.

We suspected that the patient suffered from a palytoxin poisoning caused by a blue humphead parrotfish. He was immediately treated with gastric lavage. He was also administered activated charcoal and the magnesium citrate four times a day via a nasogastric tube for the first three days.

Rhabdomyolysis was recognized from the elevated serum concentration of CK, aldolase, and myoglobin and the urine concentration of myoglobin (Table 1). Thus, a forced mannitolalkaline diuresis therapy using D-mannitol $60 \mathrm{mg}$ was also performed once a day for four days.

The serum CK was elevated to $40,000 \mathrm{IU} / l$ on the $3 \mathrm{rd}$ hospital day and recovered to a normal range on the 18th hospital day. The AST was elevated to 3,370 IU/l on the 3rd hospital day and the LDH was elevated to $7,100 \mathrm{IU} / l$ on the 4 th day, as can be seen in Fig. 2. The serum blood urea nitrogen

From the Division of Internal Medicine, Owase General Hospital, Mie, *the Second Department of Pathology, Mie University School of Medicine, Mie and **the First Department of Internal Medicine, Mie University School of Medicine, Mie

Received for publication March 28, 1997; Accepted for publication November 18, 1997

Reprint requests should be addressed to Dr. Hiroshi Okano, the Division of Internal Medicine, Owase General Hospital, 5-25 Ueno-cho, Owase, Mie 519-3653 


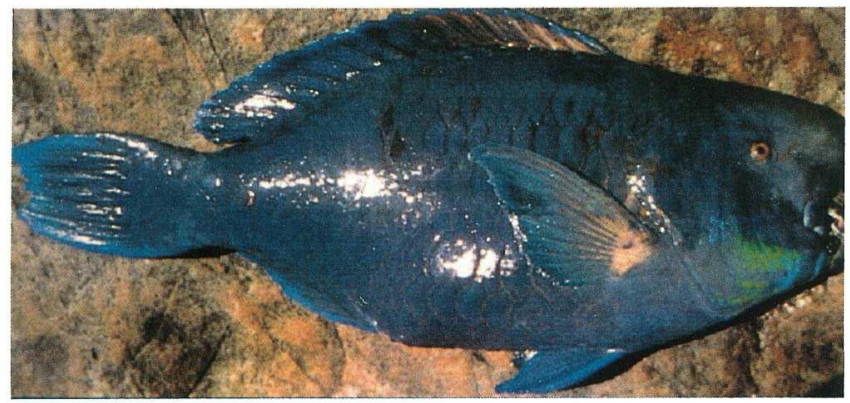

Figure 1. Ypsiscarus ovifrons ("blue humphead parrotfish" in English and "aobudai" in Japanese). Reprinted from Fisher's New Color Guide for Sport Fishermen, first, 1995: 376, Copyright (C) 1995 by WEEKLY SUNDAY FISHING Co., Ltd.

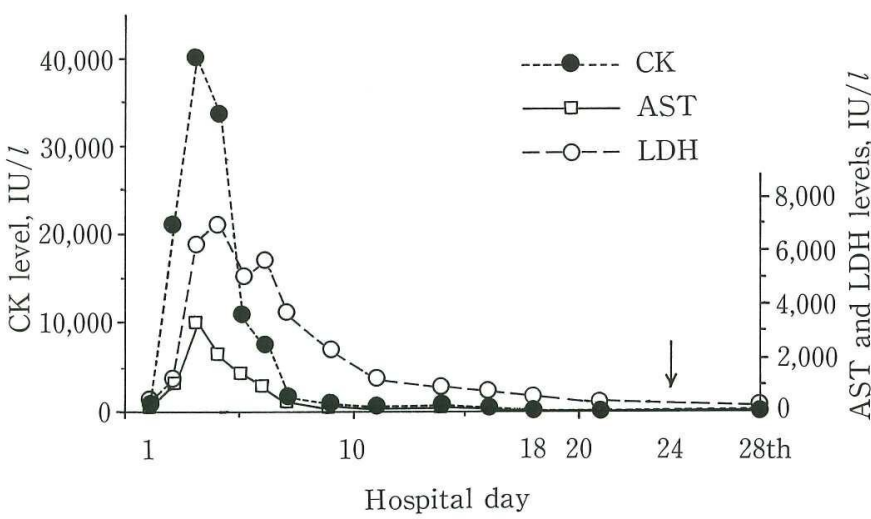

Figure 2. Clinical course of the patient. CK: creatine phosphokinase, AST: aspartate aminotransferase, LDH: lactate dehydrogenase. Arrow indicates the muscle biopsy.

(BUN) and creatinine level remained within normal range throughout the clinical course.

The serum CK-MB isozyme level on the 4th hospital day was $8.0 \%$, and negative $\mathrm{T}$ waves appeared in leads III and $\mathrm{aV}_{\mathrm{F}}$ of his electrocardiogram on the 4th hospital day (Fig. 3). The serum myosin light chain level was above $250 \mathrm{ng} / \mathrm{ml}$ on the 8 th hospital day. His echocardiography showed no abnormality throughout the clinical course.

On the 21st hospital day, a muscle biopsy from his right quadriceps muscle was taken. Histopathological study of the muscle biopsy showed no abnormalities. The muscle damage due to the palytoxin poisoning in the acute phase may have already been restored.

His weakness and myalgia of the extremities gradually became less prominent and disappeared within 4 weeks after admission.

\section{Discussion}

Palytoxin (PTX) is a water-soluble polyether compound
Table 1. Laboratory Data on Admission

Blood Cell Counts

White blood cells

Red blood cells

Hemoglobin

Hematocrit

$10,200 / \mu$

$519 \times 10^{4} / \mu 1$

$16.2 \mathrm{~g} / \mathrm{dl}$

$48.4 \%$

Platelet

$17.8 \times 10^{4} / \mu 1$

Coagulation test

Activated partial thromboplastin time $\quad 30.7 \mathrm{sec}$

Prothrombin time $\quad 104.0 \%$

Thrombin time

$150.0 \%$

Arterial blood gas (room air)

$\mathrm{pH}$

7.405

$\mathrm{PaO}_{2}$

$82.7 \mathrm{mmHg}$

$\mathrm{PaCO}_{2}$

$40.7 \mathrm{mmHg}$

$\mathrm{HCO}_{3}^{-}$

$25.5 \mathrm{mmHg}$

$\mathrm{BE}$

$1.3 \mathrm{mmHg}$

Serological test

C-reactive protein

Rheumatoid factor

Antinuclear antibodies

$4.31 \mathrm{mg} / \mathrm{dl}$ $\leq 20.0 \mathrm{IU} / \mathrm{ml}$

negative

Blood Chemistry

Total protein

Albumin

$7.7 \mathrm{~g} / \mathrm{dl}$

$4.1 \mathrm{~g} / \mathrm{dl}$

Aspartate aminotransferase (AST)

$65 \mathrm{IU} / \mathrm{l}$

Alanine aminotransferase (ALT)

$81 \mathrm{IU} / L$

Lactate dehydrogenase (LDH)

422 IU/l

$213 \mathrm{IU} / \mathrm{l}$

$47 \mathrm{IU} / \mathrm{l}$

$\gamma$-glutamyltranspeptidase $(\gamma$-GTP)

$1.3 \Delta \mathrm{pH}$

$184 \mathrm{mg} / \mathrm{dl}$

$58 \mathrm{mg} / \mathrm{dl}$

$20.4 \mathrm{mg} / \mathrm{dl}$

$0.8 \mathrm{mg} / \mathrm{dl}$

$143 \mathrm{mEq} / \mathrm{l}$

$3.6 \mathrm{mEq} / \mathrm{l}$

$95 \mathrm{mEq} / \mathrm{l}$

$695 \mathrm{IU} / \mathrm{l}$

Creatine phosphokinase (CK)

Serum myoglobin

$\geq 500 \mathrm{ng} / \mathrm{ml}$

Urea myoglobin

$\geq 500 \mathrm{ng} / \mathrm{ml}$

Serum aldolase $284.0 \mathrm{IU} / l / 37^{\circ} \mathrm{C}$

with a molecular weight of 2,678.5 (the molecular formula: $\mathrm{C}_{129} \mathrm{H}_{223} \mathrm{~N}_{3} \mathrm{O}_{54}$ ) (1). PTX was reported as a new marine toxin in 1971 by Moore and Scheuer (2). Its chemical structure was reported independently in 1981 by Moore et al and Uemura et al $(3,4)$.

PTX is the most deadly nonproteinous toxin ever isolated. Its reported $\mathrm{LD}_{50}$ of $0.15 \mu \mathrm{g}$ per $\mathrm{kg}$ (intravenous injection in mice) was 50 times more toxic than tetrodotoxin and saxitoxin (5). PTX has been revealed to have electrophysiological and pharmacological mechanisms of action. It has been proposed to act as an agonist for a family of low conductance channels that 
A

I
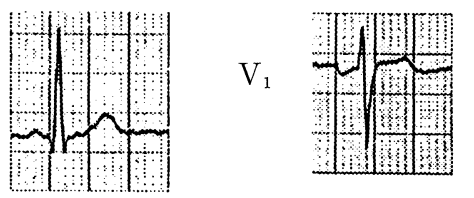

II

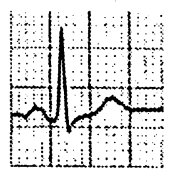

III

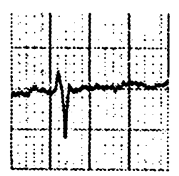

$\mathrm{a} \mathrm{V}_{\mathrm{R}}$

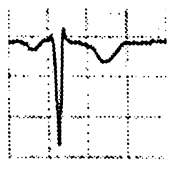

$\mathrm{V}_{4}$

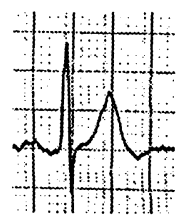

$\mathrm{V}_{2}$

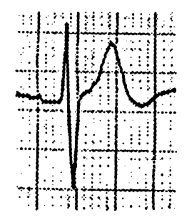

$\mathrm{V}_{3}$

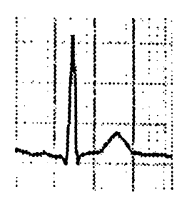

$\mathrm{aV}_{\mathrm{L}}$

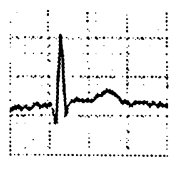

$\mathrm{V}_{5}$

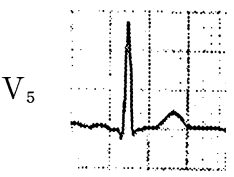

$\mathrm{aV}_{\mathrm{L}}$
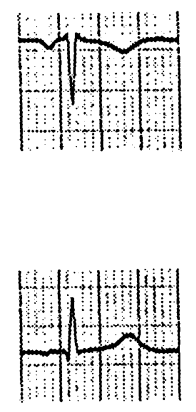

$\mathrm{aV}_{\mathrm{F}}$

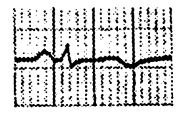

$\mathrm{V}_{4}$

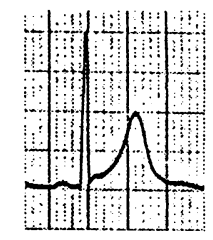

$\mathrm{V}_{5}$
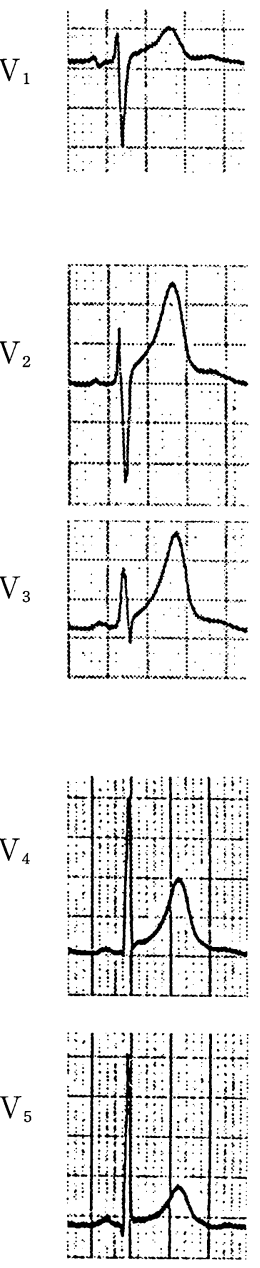

$\mathrm{V}_{2}$

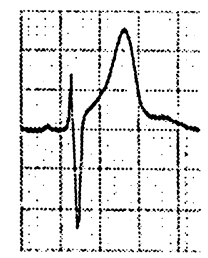

$\mathrm{V}_{3}$

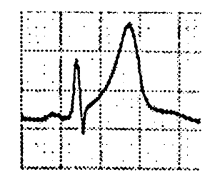

$\mathrm{V}_{6}$

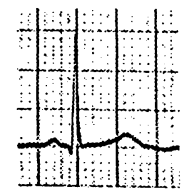

Figure 3. Electrocardiograms on admission (A) and on the 4th hospital day (B).

conduct $\mathrm{Na}^{+} / \mathrm{K}^{+}, \mathrm{H}^{+}$and $\mathrm{Ca}^{2+}$ ions (6).

PTX was first isolated from a marine zoanthid, Palythoa toxica, and later from other Palythoa species (5). PTX was reported to be the causative agent in the blue humphead parrotfish poisoning reported by Noguchi et al (7) in 1987.

Ypsiscarus ovifrons ("blue humphead parrotfish" in English and "aobudai" in Japanese) is a member of the bass order. They are usually found in small groups around rocky areas in the coastal waters of southern Japan (exclusive of the Ryukyu Islands). They live mainly on shellfishes, crabs, prawns, and seaweed (8). The total length of the grown blue humphead parrotfish is about 80 centimeters (Fig. 1); its forehead becomes enlarged with growth.

PTX was isolated from the muscle, liver, ovary and digestive tract of the blue humphead parrotfish. It has been reported that the liver is highly toxic during the summer, the spawning season $(9,10)$. PTX was also detected from a certain sea anemone and filefishes feeding on the sea anemones. It is suspected that PTX is concentrated as it is passed up the marine food chain (1).

Few reports have discussed blue humphead parrotfish poisoning $(9,11-13)$. In the previous reports, symptoms appeared within several hours after eating, with a variation of 3 to 49 hours (1). These symptoms included myalgia, prostration, dyspnea and dysphonia (1).

Rhabdomyolysis is the most dangerous complication of PTX poisoning. It may cause acute renal failure, particularly in hypovolemic or acidic patients. To prevent renal failure, an early aggressive hydration to replace fluid and an intravenous injection of sodium bicarbonate to maintain a urine $\mathrm{pH}$ of greater than 6.5 for preventing the dissociation of myoglobin 


\section{Blue Humphead Parrotfish Poisoning}

into potentially toxic compounds are very important (14).

It is noteworthy that the possibility of myocardial injury was rarely recorded for blue humphead parrotfish poisoning (11, 12). In the patient case, although the echocardiography showed no significant findings, the findings of an elevated serum concentration of myosin light chain and the change of the electrocardiograms suggested that a myocardial injury might be induced by PTX poisoning. Trahern et al reported that the assay for cardiac myosin light chain provides a biochemical marker of high sensitivity and specificity for myocardial injury (15). To our knowledge, this is the first report suggestive myocardial damage due to a PTX poisoning documented by myosin light chain assay.

\section{References}

1) Ishizawa J, Tsujikawa A, Oohashi N. Gekkann Yakuji 37: 163, 1995 (in Japanese).

2) Moore RE, Scheuer PJ. Palytoxin: a new marine toxin from a coelenterate. Science 172: 495, 1971.

3) Moore RE, Bartolini G. Structure of palytoxin. J Am Chem Soc 103: 2491, 1981.

4) Uemura D, Ueda K, Hirata Y. Further studies on palytoxin. II. Structure of palytoxin. Tetrahedron Letters 22: 2781, 1981.

5) Shimizu Y. Complete structure of palytoxin elucidated. Nature 302: 212,
1983 (news).

6) Frelin C, Van Renterghem C. Palytoxin. Recent electrophysiological and pharmacological evidence for several mechanisms of action. Gen Pharmacol 26: 33, 1995.

7) Noguchi T, Hwang DF, Arakawa O. Palytoxin as the causative agent in the parrotfish poisoning. Progress in Venom and Toxin Research, Faculty of Medicine, National University of Singapore, 1987, p. 325.

8) Masuda H. Coastal Fishes of Southern Japan. Tokai Daigaku Shuppan, 1st edition, 1975, p. 308.

9) Watanabe S, Morioka E, Ooishi A, et al. Fish poisoning caused by ingesting parrotfish, is it ciguatera? Kyukyu Igaku 10: 443, 1986 (Abstract in Japanese).

10) Fusetani N, Sato S, Hashimoto K. Occurrence of a water soluble toxin in a parrotfish (Ypsiscarus ovifrons) which is probably responsible for parrotfish liver poisoning. Toxicon 23: 105, 1985.

11) Ichida $S$, Tawada $E$, Watanabe $Y$, Minami S, Horiba M. Two cases of rhabdomyolysis induced by parrotfish liver poisoning. Jin to Toseki 25: 157, 1988 (in Japanese).

12) Akatsuka $Y$, Minami $S$, Ichida $S$, et al. The parrot fish poisoning. Chudoku Kenkyu 2: 63, 1989 (in Japanese).

13) Amano M, Imamura R, Kawanishi R, et al. Intoxication probably caused by consumption of parrotfish liver. Japanese journal of Internal Medicine 36: 662, 1975 (in Japanese).

14) Gergory AE, Clark RM. Manual of Medical Therapeutics. Little, Brown and Company, Boston, 28th edition, 1995, p. 265.

15) Trahern CA, Gere JB, Krauth GH, Bigham DA. Clinical assessment of serum myosin light chains in the diagnosis of acute myocardial infarction. Am J Cardiol 41: 641, 1978. 